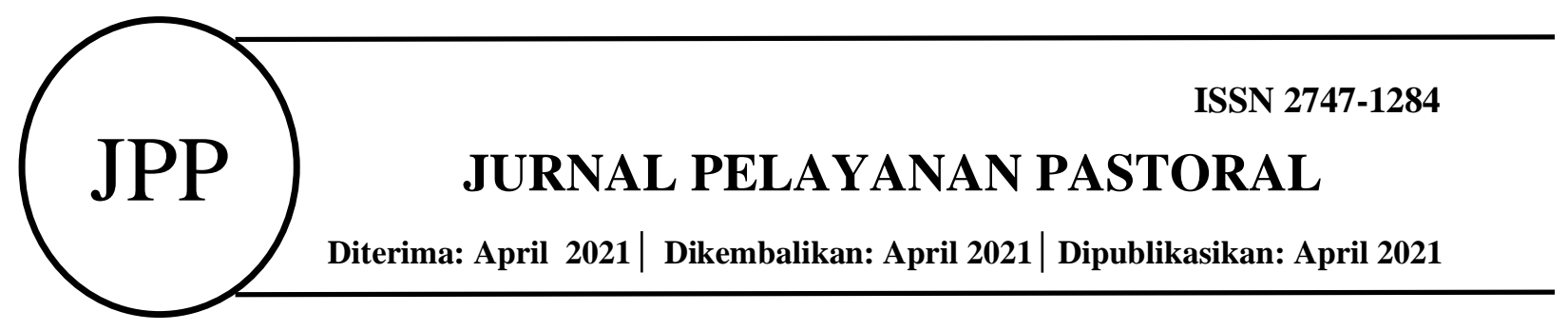

\title{
PERAN DAN SIKAP PENGASUH TERHADAP ANAK TUNARUNGU-WICARA DI KOMPLEKS HALIMUN BHAKTI LUHUR MALANG
}

\author{
${ }^{1}$ Klemensia Nini, ${ }^{2}$ Yustina Muinesu \\ ${ }^{1}$ Dosen Prodi Pelayanan Pastoral, ${ }^{2}$ Mahasiswa Prodi Pelayanan Pastoral \\ e-mail: haremensi@gmail.com.yustinamuinnesu2@gmail.com
}

\begin{abstract}
Abstrak
Peran dan sikap pengasuh sangat berdampak pada pertumbuhan dan perkembangan baik fisik maupun psikis terutama terhadap anak tunarungu wicara. Semakin baik peran dan sikap pengasuh terhadap anak tunarungu-wicara, semakin baik pula pertumbuhan dan perkembangannya. Sebaliknya semakin lemah peran dan sikap pengasuh terhadap anak tunarungu wicara maka semakin buruk pula pertumbuhan dan perkembangannya. Tugas para pengasuh tidak cukup hanya dengan memperhatikan kebutuhan fisiknya saja tetapi juga harus memperhatikan kebutuhan psikologisnya seperti kasih sayang, perhatian, rasa aman, dan lain-lain. Tujuan penelitian ini adalah untuk menggambarkan bagaimana peran dan sikap pengasuh terhadap anak tunarungu wicara di kompleks Bhakti Luhur Halimun serta faktor pendukung dan penghambat peran dan sikap pengasuh ketika mendampingi anak tunarungu wicara. Penelitian ini adalah penelitian kualitatif - deskriptif. Metode pengumpulan data menggunakan wawancara, observasi dan dokumentasi. Temuan penelitian ini adalah 1) Sikap kurang sabar ditunjukkan oleh pengasuh pada waktu mendampingi tunarungu-wicara, 2) Pengasuh kurang terampil dalam berkomunikasi dengan anak tunarungu-wicara, 3) Pengasuh menampilkan sikap yang kurang tepat seperti mendiamkan dan mengabaikan anak tunarungu -wicara bila ada konflik dengannya, 4) Ada usaha dari pengasuh untuk bersikap lemah lembut terhadap anak tunarunguwicara, 5).Sikap beberapa pengasuh terhadap anak tunarungu-wicara adalah rasa kasihan yang mendorong pengasuh untuk memberikan perhatian yang berlebihan, 6). Ada usaha dari beberapa pengasuh untuk memahami karakter anak sehingga dapat membantu mengarahkan anak, 7) Beberapa pengasuh berusaha mempelajari bentuk komunikasi yang digunakan oleh anak meskipun terbatas.8) Peran dapat dijalankan dengan baik hanya saja kurang dibarengi sikap hati yang memadai.
\end{abstract}

Kata kunci: Peran dan sikap pengasuh, anak tunarungu-wicara

\begin{abstract}
The roles and attitudes of caregivers greatly affect the growth and development of both physical and psychological, especially for children with hearing impairments. The better the role and attitude of caregivers towards speechimpaired children, the better their growth and development. On the other hand, the weaker the role and attitude of caregivers towards speech-impaired children, the worse their growth and development will be. It is not enough for caregivers to only pay attention to their physical needs but also to pay attention to their psychological needs such as affection, attention, security, and others. The purpose of this study was to describe how the role and attitude of caregivers towards speech-impaired children in the Bhakti Luhur Halimun complex as well as the supporting and inhibiting factors of the role and attitude of caregivers when accompanying speech-impaired children. This research is qualitative descriptive research. Methods of data collection using interviews, observation, and documentation. The findings of this study are 1) An impatient attitude is shown by caregivers when accompanying speech-deaf children, 2) Caregivers are less skilled in communicating with speech-deaf children, 3) Caregivers display inappropriate attitudes such as silencing and ignoring speech-deaf children if there are any. conflict with him, 4) There is an attempt by the caregiver to be gentle with the speech-impaired child, 5). The attitude of some caregivers towards the speechimpaired child is pity that drives the caregiver to give excessive attention, 6). There are efforts from some caregivers to understand the child's character so that it can help direct the child, 7) Some caregivers try to learn the form of communication used by the child even though it is limited. 8) The role can be carried out well, but it is not accompanied by an adequate attitude a heart.
\end{abstract}

Keywords: Roles and attitudes of caregivers, children who are deaf-speech 


\section{PENDAHULUAN}

Pengasuh adalah orang tua pengganti yang bertugas untuk mengasuh, merawat, mendidik demi tercapainya pertumbuhan dan perkembangan secara optimal. Tugas ini diatur dalam Undang-Undang Republik Indonesia Nomor 8 tentang penyandang disabilitas. Pasal 6 undangundang ini mengatakan bahwa hak hidup penyandang disabilitas meliputi mendapatkan perawatan dan pengasuhan yang menjamin kelangsungan hidupnya. Pasal tersebut di atas berkaitan langsung dengan peranan pengasuh. Peranan pengasuh di sini tidak sekedar mengasuh karena tugasnya demikian melainkan lebih dari itu adalah menjalankan kewajiban penting yakni memberikan hak hidup bagi yang diasuh.

Menurut Soekanto, arti peran yaitu suatu pekerjaan yang dilakukan dengan dinamis sesuai dengan status atau juga kedudukan yang disandang. Status serta kedudukan tersebut sesuai dengan keteraturan sosial, bahkan dalam keteraturan tindakan semuanya itu disesuaikan dengan peran yang berbeda. ${ }^{1}$ Jadi jika dikaitkan dengan pengasuh anak tunarungu maka dapat dijelaskan bahwa peran pengasuh atau pengganti orang tua adalah orang yang bertanggung jawab sesuai statusnya yakni merawat, membesarkan dan mendidik.

Peran orang tua yang ideal bagi anak adalah membagi waktu antara pekerjaan dengan anak ataupun keluarga. Peran dalam keluarga adalah mendidik dan membimbing anak ke jalan yang lebih baik, seperti menanamkan nilai dan norma pada anaknya yang sudah mulai luntur, selalu mengawasi anak, dengan siapa sang anak berteman, menjadi sahabat sekaligus teman curahan hati (curhat) bagi anak agar anak tidak memilih teman yang salah. Dalam menjalankan perannya ada sisi positif antara orang tua dan anak yakni hubungan antara mereka akan semakin dekat dan akrab.

Ketika peran orang tua digantikan oleh seseorang yang disebut pengasuh maka hendaknya hal-hal yang seharusnya menjadi tanggung jawab orang tua sedapat mungkin digantikan dengan optimal. Jadi dengan kata lain pengasuh adalah orang yang bertanggung jawab atas proses pertumbuhan dan perkembangan yang diasuh. Pengasuh juga merupakan orang yang memainkan peran-peran tertentu sesuai dengan kedudukan dan fungsinya.

Mengasuh, merawat dan mendidik anak tunarungu yang diperankan oleh pengasuh menuntut sikap yang ideal. Bimo Walgito menyimpulkan pengertian sikap dari beberapa ahli yaitu bahwa "sikap itu merupakan organisasi pendapat, keyakinan seseorang mengenai obyek atau situasi yang relatif ajeg, yang disertai adanya persatuan tertentu, dan memberikan dasar kepada orang tersebut untuk membuat respons atau perilaku dalam cara yang tertentu yang dipilihnya" (Walgito, 2003: 127). Merujuk pada pengertian di atas maka dapat dijelaskan bahwa sikap merupakan faktor yang ada dalam diri manusia yang mendorong seseorang untuk berperilaku tertentu sesuai dengan pilihannya.

Sikap berkaitan erat dengan perilaku maka sikap perlu dibentuk dan dipelajari. Terbentuknya sikap dilakukan sepanjang perkembangan individu yang bersangkutan. Jika orang memahami dengan baik dan mengerti serta terampil menghadapi tunarungu dan dunianya maka sangat mungkin timbul hubungan yang hangat dan positif di antara mereka. Ketika seseorang memandang anak tunarungu sebagai anak yang sulit dan tidak mudah diatur maka cara orang merespons apa yang menjadi hak dan kebutuhan anak itu sangat mungkin bersifat negatif misalnya mengabaikan, atau bahkan tindak kekerasan dapat terjadi.

Masalah peran dan sikap menjadi sebuah tantangan tersendiri bagi orang tua maupun pengasuh terutama pengasuh anak tunarungu. Anak tunarungu adalah anak yang karena suatu hal misalnya kerusakan organ pendengaran ataupun syaraf-saraf pendengarannya sehingga

\footnotetext{
${ }^{1}$ https://www.seputarpengetahuan.co.id/2019/10/peran.html. Diakses 19 Maret 2020. Pkl. 20:30 wib.
} 
mengakibatkan mereka mengalami kehilangan fungsi pendengaran. Kehilangan fungsi pendengaran ini berdampak pada berbagai aspek perkembangan. Dampak yang paling besar adalah hambatan dalam berkomunikasi. Hambatan ini tentu saja merupakan akibat dari ketidakmampuan tunarungu merespons suara, percakapan, dan belajar bahasa maupun bicara secara spontan. Akibat selanjutnya adalah kemiskinan kosa kata yang berdampak pada terhambatnya komunikasi antara anak tunarungu dan orang lain di sekitarnya.

Kesulitan dalam berkomunikasi antara tunarungu dan orang lain di lingkungan sekitarnya perlu dilatih secara baik, benar dan konsisten. Ketika anak tunarungu memiliki kemampuan bahasa dan bicara yang memadai, tunarungu dimungkinkan mampu berinteraksi dengan lingkungan termasuk mampu memahami dan akhirnya menerima segala bentuk ajaran atau norma-norma yang berlaku dimasyarakat. Hal ini tentu saja berimbas pada pembentukan kepribadian yang baik.

Selain kebutuhan sosialnya orang tua maupun pengasuh perlu memperhatikan kebutuhan fisik anak seperti tempat tinggal, makanan, pakaian, dan kehangatan. Di samping itu diperlukan kesadaran bahwa anak tunarungu perlu menerima apa yang menjadi hak-hak hidupnya. Hak hidup yang dimaksudkan di sini adalah bebas dari penelantaran, pemasungan, pengurungan dan pengucilan. Bebas dari ancaman dan berbagai bentuk eksploitasi dan bebas dari penyiksaan, perlakuan dan penghukuman lain yang kejam, tidak manusiawi, dan merendahkan martabat manusia.

Dalam kasus yang ditemui oleh peneliti di salah satu wisma anak berkebutuhan khusus kompleks Halimun, seorang anak tunarungu wicara tumbuh menjadi seorang anak yang susah diatur dan hanya takut atau menurut pada pengasuh tertentu. Perilaku suka memberontak terhadap pengasuh, acuh kerakali muncul. Tidak begitu jelas pemicunya namun biasanya perilaku itu muncul ketika tunarungu merasa tidak dimengerti. Hal ini menurut peneliti bisa dipengaruhi oleh pola asuh yang salah ketika anak itu masih kecil. Berdasarkan informasi yang diterima peneliti dari penanggung jawab wisma tersebut bahwa anak ini dititipkan olah orang tuanya sejak umur kurang lebih 7 tahun. Orang tua mengalami kesulitan mengasuh anak dengan kelainan pendengaran dan wicara. Kesulitan yang dihadapi oleh orang tua ini dapat dipahami. Sepanjang 7 tahun kehidupan anak tidak bersekolah dan dampak selanjutnya adalah banyaknya ketinggalan dan keterbelakangan yang dialami anak tunarungu ini.

Situasi tersebut di atas menuntut peran dan sikap yang ideal dari seorang pengasuh atau pengganti orang tua. Akan tetapi sejauh mana para pengasuh memainkan peran mereka sebagai pengasuh sangat bergantung pada bagaimana pengasuh merespons keadaan anak tunarungu yang dihadapinya. Bila pengasuh sedikitnya memiliki sikap hati yang terbuka menerima keadaan anak apa adanya, sangat mungkin baginya untuk mengupayakan pola-pola pembinaan yang baik untuk anak tunarungu. Dampaknya adalah anak merasa bahwa kebutuhan hidup yang menjadi haknya terpenuhi, dan kemandirian hidup kelak juga terjamin.

\section{METODE PENELITIAN}

Metode yang digunakan dalam penelitian ini adalah metode kualitatif dengan pendekatan fenomenologi. Pendekatan fenomenologi bermaksud untuk mencari hakikat atau esensi dan pengalaman, (Raco, 2010: 21). Penelitian fenomenologi mencoba menjelaskan atau mengungkap makna konsep atau fenomena pengalaman yang didasari oleh kesadaran yang terjadi pada beberapa individu. Fenomenologi dilakukan dalam situasi yang alami, sehingga tidak ada batasan dalam memaknai atau memahami fenomena yang dikaji dan peneliti bebas untuk menganalisis data yang diperoleh.

Metode pengumpulan data menggunakan wawancara, observasi dan dokumentasi. 
Informan kunci adalah satu orang pengasuh yang diberi tanggung jawab mendampingi anak tunarungu di wisma Yohanes bawah. Dan sebagai informan pendukung adalah satu orang ibu asrama dan tiga orang perawat yang berdomisili di wisma Yohanes bawah.

Penelitian ini menggunakan pendekatan fenomenologi karena didukung oleh fakta bahwa: 1) data dalam penelitian ini adalah data yang tampak di permukaan termasuk sikap dan perilaku aktor yang diteliti, 2) penelitian ini juga mau mengungkap bagaimana peran dan sikap pengasuh terhadap anak tunarungu-wicara, 3) fokus dari penelitian ini adalah melihat bagaimana para pengasuh menampilkan sikap dan memainkan perannya dalam pengasuhan anak tunarungu di wisma Yohanes Bhakti Luhur Malang.

\section{HASIL DAN PEMBAHASAN \\ Teori Peran}

Istilah peran dalam "Kamus Besar Bahasa Indonesia" mempunyai arti pemain sandiwara (film), peran atau tingkah yang diharapkan dimiliki oleh orang yang berkedudukan di masyarakat. Peran yaitu merupakan aspek dinamis kedudukan (status), apabila seseorang melakukan hak dan kewajiban sesuai dengan kedudukannya, maka ia menjalankan suatu peranan.

Dalam kehidupan bermasyarakat kita mengenal adanya norma. "Norma adalah harapan bersama", (Boerre, 2020:122). Harapan bersama umumnya ditafsirkan sebagai perilaku atau kebiasaan yang diharapkan oleh masing-masing anggota kelompok agar dipatuhi dan dijalankan dengan baik, Boeree, 2020: 122). Jadi peran adalah harapan bersama yang menyangkut fungsi di tengah masyarakat. Lebih lanjut George Boerre mendefinisikan peran yang melibatkan "fungsi. Baginya peran tidak memiliki makna apabila tidak memiliki fungsi tertentu yakni fungsi yang bermanfaat di tengah masyarakat.

Terdapat berbagai jenis peran dan beberapa di antaranya bersifat formal sementara beberapa yang lain bersifat tidak formal dan berlaku hanya sementara atau hanya diemban dalam waktu singkat. peran yang bersifat formal berarti peran yang disandang oleh mereka yang dianugerahi gelar resmi misalnya guru, dokter, perawat dan lain-lain. Mereka yang menyandang gelar tersebut diharapkan dapat menjalankan perannya dengan baik.

\section{Teori Sikap}

Sikap berkaitan erat dengan perilaku. Para ahli ilmu psikologi sosial menempatkan masalah sikap sebagai problem sentral karena merupakan masalah yang penting dan menarik. Myers dalam (Walgito, 2003:125) mengatakan bahwa orang tidak dapat mengukur sikap secara langsung maka yang dilakukan adalah mengukur sikap yang tampak yang disebut juga perilaku. Jadi perilaku dan sikap saling berinteraksi dan saling mempengaruhi satu sama lain, (Walgito, 2003: 125). Para ahli mendefinisikan sikap dari berbagai sudut pandang. Gerungan dalam (Walgito, 2003:127) menyebut sikap atau attitude dapat dimengerti sebagai sikap terhadap objek tertentu, yang dapat merupakan sikap pandangan atau sikap perasaan tetapi sikap sikap mana yang disertai oleh kecenderungan bertindak sesuai dengan objek tadi. Jadi attitude lebih tepat diterjemahkan sebagai sikap dan kesediaan bereaksi terhadap sesuatu hal.

\section{Teori Tentang Peran Pengasuh}

Menurut Direktorat Pendidikan Anak Usia Dini, peran pengasuh adalah seseorang yang memiliki kemampuan untuk memberikan pelayanan pengasuhan dan perawatan kepada anak untuk menggantikan peran orang tua yang sedang bekerja atau mencari nafkah. Jadi pengasuh dapat dimengerti sebagai orang yang memiliki keterampilan untuk mengasuh, merawat, mendidik 
dan mendampingi anak dan bertanggung jawab atas pertumbuhan dan perkembangan anak yang diasuh, (Selatang \& Neonbasu, 2020). Jadi di sini pengasuh memegang peranan penting terhadap proses perkembangan seorang anak.

\section{Teori Tentang Tunarungu}

Secara umum tunarungu dapat diartikan sebagai suatu keadaan di mana seseorang tidak dapat mendengar karena fungsi organ pendengaran mengalami kerusakan atau gangguan. Kerusakan ataupun gangguan pendengaran ini secara umum digolongkan ke dalam dua kategori besar yakni kurang dengar dan tuli atau tidak dapat mendengar sama sekali. Besar kecilnya tingkat kehilangan pendengaran seseorang akan sangat berpengaruh terhadap kemampuan berbicara dan berkomunikasi. Semakin berat gangguan pendengaran seseorang maka semakin besar pula hambatan dalam proses perolehan informasi selanjutnya bila proses perolehan informasi melalui pendengaran sangat minim bahkan tidak terjadi maka dampaknya ialah minim kosa kata. Beberapa hambatan yang utama akibat hilangnya fungsi pendengaran adalah aspek perkembangan bahasa, kecerdasan dan penyesuaian sosial.

\section{Peran dan Sikap Pengasuh Terhadap Anak Tunarungu}

Hasil wawancara dan observasi peneliti terhadap lima informan menunjukkan bahwa ada berbagai ragam sikap yang ditunjukkan oleh pengasuh terhadap anak tunarungu wicara. Kelima informan masing-masing mengemukakan pandangan yang berbeda terutama tentang sikap yang mereka tunjukkan terhadap anak tunarungu wicara. Ada yang bersikap membiarkan, bersikap kasar dan marah, ada yang bersikap acuh tak acuh, ada pula yang bersifat memanjakan dalam arti selalu memberi upah/imbalan bila anak mau menuruti perintah pengasuh, namun ada pula yang bersikap sabar dan penuh perhatian. Situasi di atas dapat disimpulkan bahwa sikap pengasuh dalam konteks ini dapat dikatakan lebih cenderung menunjukkan sikap negatif. Sikap negatif ini muncul karena perbedaan cara pandang dari masing-masing pengasuh.

Bimo Walgito mengatakan bahwa sikap seseorang dapat terbentuk dalam perkembangan individu yang bersangkutan maka sikap dapat berubah meskipun demikian sikap mempunyai kecenderungan adanya sifat yang tetap, (Walgito, 2003: 131). Selanjutnya dikatakan bahwa sikap akan selalu terbentuk atau dipelajari dalam hubungan dengan objek tertentu, yakni melalui persepsi terhadap objek tersebut, (Walgito, 2003: 132). Dengan demikian bila terdapat hubungan yang positif ataupun negatif antara individu dengan objek tertentu, akan menimbulkan sikap tertentu pula dari individu terhadap objek tersebut.

Hasil wawancara dan didukung dengan observasi terhadap pengasuh sehubungan dengan peran pengasuh terhadap anak tunarungu ditemukan bahwa pengasuh telah berusaha menjalankan perannya dengan baik meskipun kadang-kadang sedikit lalai. Peran yang dimaksudkan adalah membimbing, mendampingi mendidik dan memperhatikan kebutuhan anak yang menjadi tanggung jawabnya.

Sebagai pembimbing, pengasuh berusaha memahami bahasa isyarat yang digunakan oleh anak meskipun tidak selalu. Sebenarnya dengan menguasai bahasa isyarat yang digunakan anak maka hubungan komunikasi antara pengasuh dengan anak menjadi lebih baik. Namun dalam kenyataannya berdasarkan hasil observasi peneliti, pengasuh tampak sangat minim melakukan interaksi dengan anak. Hal ini dikarenakan penguasaan bahasa isyarat yang minim dan juga ketidaksepahaman penggunaan bahasa isyarat antara pengasuh dan anak.

Berperan sebagai pendidik, pengasuh berusaha mendampingi anak menyelesaikan tugastugas sekolah dengan baik. Selain itu melibatkan anak tunarungu dalam berbagai kegiatan bersama 
dan memberikan tanggung jawab tugas sederhana seperti membersihkan rumah, mencuci pakaiannya, memasak satu jenis masakan sederhana dan kegiatan lain yang bersifat melatih kemandirian anak untuk kehidupannya kelak. Situasi yang digambarkan oleh peneliti sehubungan dengan peran maka dapat disimpulkan bahwa pengasuh pada dasarnya sudah menjalankan perannya sebagai pengasuh yakni merawat, membimbing, mendidik dan bertanggung jawab atas perkembangan anak yang diasuh.

\section{KESIMPULAN}

Berdasarkan wawancara dan observasi terhadap lima informan sehubungan dengan peran dan sikap pengasuh terhadap anak tunarungu-wicara dapat disimpulkan beberapa hal sebagai berikut: Pertama: terdapat keragaman sikap para pengasuh dalam menghadapi anak tunarungu wicara. Sikap-sikap yang lebih dominan adalah sikap-sikap yang negatif terhadap anak yang kemudian berpengaruh terhadap munculnya perilaku tidak patuh atau suka memberontak. Kedua: meskipun dominan sikap yang ditunjukkan adalah sikap negatif namun masih ada satu pengasuh yang cenderung memiliki sikap positif dalam arti memahami dan bertindak lebih lemah lembut namun tegas bila anak menunjukkan perilaku memberontak atau lalai dalam tugas. Sikap yang demikian membuat anak tunarungu wicara lebih cenderung taat dan lebih menurut pada pengasuh bersangkutan. Ketiga: pada umumnya para pengasuh bisa menjalankan perannya sebagai pengasuh yakni dalam hal merawat, mendidik, membimbing dan menyediakan kebutuhan yang diperlukan anak. Namun di sisi lain cara melaksanakan bimbingan bagi anak tunarungu belum disertai sikap lemah lembut dan sabar. Selain itu keseragaman dalam berkomunikasi antara anak tunarungu dan pengasuh belum terjalin baik sehingga sangat sukar bagi mereka untuk berinteraksi dengan lebih baik. Berdasarkan kesimpulan di atas maka beberapa saran dapat diberikan yakni (1) Pembinaan sikap para pengasuh yang nota bene masih berusia belia (SMA) perlu dilakukan secara berkala khususnya dalam menghadapi tunarungu-wicara, (2) Peningkatan latihan bahasa isyarat perlu dilakukan baik untuk anak maupun untuk pengasuh, (3) sangat perlu bagi para pengasuh mengetahui riwayat dan latar belakang kehidupan anak sebagai bahan pertimbangan dalam pengasuhan dan pembinaan anak selanjutnya. 


\section{DAFTAR PUSTAKA}

Selatang, F., \& Neonbasu, J. (2020). BIAK: Ruang Interaksi Sosial antar Penyandang Disabilitas. Jurnal Pelayanan Pastoral, 1(1), 16-24.

Boeree George C. (2020). Dasar-Dasar Psikologi Sosial. Yogyakarta: Buku Bijak

J. R. Raco, ME. (2010). Metode Penelitian Kualitatatif, Jakarta : Gramedia Widiasarana Indonesia.

Glazzard, Jonathan dkk. (2016). Asih Asah Asuh Anak Berkebutuhan Khusus di Sekolah Dasar. Yogyakarta: Kanisius.

Efendi, Mohammad. (2009). Pengantar Psikopedagogik Anak Berkelainan. Jakarta: PT. Bumi Aksara.

Mangunsong, Frieda. (2014). Psikologi Anak Berkebutuhan Khusus jilid kesatu. Depok: LPSP3 UI.

Tim Indepth Right. (2016). Hak-Hak Penyandang Disabilitas. Malang: Karmelindo.

Walgito, Bimo. (2003). Psikologi Sosial (sebuah Pengantar). Yogyakarta: Andi Offset. https://www.seputarpengetahuan.co.id/2019/10/peran.html. Diakses 19 Maret 2020. 